\title{
Investment Opportunities \& Liquidity Constraints: Evidence from Two Emerging Markets, India and Pakistan
}

\author{
Dr. Muhammad Sadiq Shahid ${ }^{1}$ \\ Dr. Faid Gul ${ }^{2}$
}

\begin{abstract}
This paper examines the relationship between the investment opportunities and liquidity constraints in the two South Asian emerging markets, i.e. India and Pakistan, over the period of 2010-2015. It reveals that there is a significant relationship between a firm investment opportunities and liquidity constraints. Using pooled OLS fixed effect model, we find a significant negative association between stock illiquidity (external liquidity constraint) and investment opportunities in both BSE and KSE firms. We also find a significant impact of firm's cash flow to total assets ratio (internal liquidity) on firm's investment opportunities. The results are statistically significant for both internal and external liquidity and investment opportunities in the presence of control variables like market-to-book ratio, size, leverage, and dividend payout ratio. Similarly, the results are robust for both emerging markets. The findings of this study are consistent with the findings of previous literature that liquidity is positively related to firm's investment opportunities. Our study further clarify that both internal and external liquidity are important for firm's investment opportunities.
\end{abstract}

Keywords: investment opportunities, internal liquidity, external liquidity, firm size, leverage, payout ratio

JEL Code : G31, G35, L25, O53

\section{INTRODUCTION}

Liquidity is one of the fundamental factors affecting the investor confidence in the security market. It is generally recognized that liquidity is important for asset pricing due to its ability to sell stocks quickly at a fair value. Recent events in financial markets have revealed that liquidity acts as one of the most important market frictions that influence asset prices. The theoretical literature explains that the negative association of equity returns with costs of trading stems from the market microstructure where liquidity is an important factor (Bekaert, Harvey \& Lundblad, 2007; Gregoriou \& Ioannidis, 2006).

Amihud \& Mendelson (1988) determine that stock liquidity has a positive association with market capitalization, because firm assets are valued at less capital cost during an increase in stock liquidity. While Myers (1977) point out that when stock liquidity increases (decreases) then a firm's cost of capital falls (rises). Similarly, Becker-Blease \& Paul (2006) provide evidence that reduction in cost of capital is a result of enhancement in stock liquidity that increases the benefits of shareholders by increasing the pool of positive NPV projects available for firm to invest in. The existing literature emphasises on investment in fixed assets, which is an important contributing factor of growth (Bond, Leblebicioğlu \& Schiantarelli, 2010; Ding, Guariglia, \& Knight, 2013; Ding \& Knight, 2011).

1. Department of Business Administration BZU, Multan.
2. Faculty of Management Sciences NUML, Islamabad, E-mail: fgul@numl.edu.pk

\begin{tabular}{lll}
\hline JISR-MSSE & Nolume 1 & Number 15
\end{tabular}

Jan-June 2017 
Ding et al. (2013) determine a progressive relationship between fixed assets investment and development. They find taht those firms whose rate of fixed assets investment declines their stock returns also decrease. They study the role of working capital management to explain that the Chinese firms invested at very high rates in spite of financial constraints. Further, they confirmed that sample firms characterized a very high average ratio of working capital to fixed capital (66.6\%), although working capital and fixed capital are highly reversible and firms can easily adjust them (Carpenter et al., 1994). Fazzari \& Petersen (1993) conduct a similar study for USA firms and find that US firms are able to stabilize cash flow fluctuations with working capital.

It is evident from my studies that inside funds are an essential determinant of investment in most developed markets. There are also some studies conducted in developing and emerging countries (Bekaert, Harvey \& Lundblad, 2003). Budina, Garretsen, \& De Jong (2000), for example, analyse the impact of liquidity constraints on investment performance by using Bulgarian firm data from 1993-1995. They conclude that the Bulgarian firms had liquidity constrained, and firm's size and capital structure are significant to differentiate between those having liquidity constraints and those having no liquidity constraints. Moreover, they established that liquidity constraints can be given a different explanation in the case of developing markets as compared to developed economies.

In this study we attempt to study the relationship between the investment opportunities and liquidity (both internal and external) in the two South Asian emerging economies i.e. India and Pakistan. International rating agencies and foreign investors show a deep interest in the emerging markets for the future investment. Internal liquidity is measured through cash flow generated by firms whereas external liquidity is measured through effective spread of stock. In fact a higher effective spread is measure of external illiquidity of a firm's stocks. Internal liquidity plays a vital role in the investment opportunities. Firms with good cash flow or access to internal financing have better investment opportunities as compared to those where internally generated financing is limited. Similarly, firms with higher external liquidity can generate external financing with ease by issuing new stocks to undertake new investment opportunities. Currently, there is limited work research work available on the liquidity constraints and investment opportunities in emerging markets. Same is the case for South Asian markets, in general and Pakistan in particular, where no such study is available, at least in our knowledge, on this particular topic. Therefore, this study fills the gap by adding to the existing literature on emerging markets by providing evidence on the South Asian emerging markets such as Pakistan and India. Similarly, this study provides a comparative analysis of Pakistan and India. For this study we select firms from Bombay Stock Exchange (BSE) and Karachi Stock Exchange (KSE).

\section{LITERATURE REVIEW}

A large number of researchers have examined the relationship between investment opportunities and liquidity constraints in the developed economies by analyzing different factors for the particular country or firms. In this section the historical literature is reviewed to get insight for the current study. This literature review is categorised as per the ideas and methodologies used by different researchers. 
Myers \& Majluf (1984) discuss the importance of undertaking valuable investment opportunities from the mode of issuing common stock (external liquidity) to generate cash flow in the market. Their findings show that firms with higher internal liquidity can undertake more investment opportunities. External financing such as issue of bonds increase the level of risk as it generates more debt to the company. Firms that have excessive cash flows (internal liquidity) should undertake better investment opportunities instead of issuing more risky securities to finance the investment which is usually pursued in the interest of existing shareholders. Their findings are consistent with pecking order theory of capital structure. Nevertheless, when firms are generating external equity then the higher external liquidity decreases the floatation cost and thus decreasing the weighted average cost of capital (WACC). Lower WACC enables firms to undertake more investment opportunities. Thus, both internal and external liquidity has a positive relationship with investment opportunities. Denis (1994) analyse the reaction of the market towards primary seasonal equity offerings and measures of profitability regarding issues of the firm's growth opportunities. Using the data of 435 US listed firms from 1977-1990, he finds a significant positive relation between growth opportunities and announcement period prediction errors.

Levine \& Zervos (1996) study the association between economic growth and the financial development by using certain measures such as liquidity, volatility, integration and size of the stock market from 1976-1993 for 49 countries. The study uses two measures of stock price movements and stock trading. Findings reveal that there is a strong positive association between economic growth and the financial development and also propose that the financial factors, including liquidity, are an essential part for the growth of the process.

Campello et al. (2011) examine how firms manage liquidity and corporate investment during a financial crisis by employing a unique dataset from 2008-2009. They show an insight on relation between external liquidity, internal liquidity, and real corporate decisions. Overall, the results indicate that liquidity eased the impact of the financial crisis on corporate investment opportunities. Chen \& Chen (2012), in a study of 334 firms from 1970-1984, do not find any relationship between cash flow sensitivities (liquidity) and financial constraints (investment opportunities). The smooth functioning of the stock market for the long run of the economic growth was examined by Zervos \& Levine (1999) by employing 31 countries data from 1976-1993. The results show a positive significant relation between overall stock market liquidity and growth opportunities and capital accumulation in an economy, even after controlling for many other related variables which effect growth opportunities.

Moyen (2004) finds that investment and cash flow sensitivities do not show a significant positive relation with financial constraints. Carpenter \& Petersen (2002) classify the positive and the negative effects based on the different aspects of the corporate sensitivity towards cash flow. These empirical analyses have lead to primary dimensions. Firstly, Kaplan \& Zingales (1997) results lack the heterogeneity in the sample. Secondly, the financial constraints in the KZ demonstrate a low sensitivity of all which are distressed in a piece of information.

Cash flows are being influenced directly by the financial market, which has been explored by Subrahmanyam \& Titman (2001). A large stock price movement is expected either in the discounted rates or in the future cash flows by using the traditional valuation model. Beck \& Levine (2004) examine the impact of banks and stock markets liquidity on the economy using 
a panel data. Their results indicate that there is a strong relationship between the stock market and bank liquidity with the economic growth in the market.

Becker-Blease \& Paul (2006) examine the relationship between firm investment opportunities and the stock liquidity. Non-financial firms from the Standard and Poor's (S\&P) 500 index are selected as sample and data over the period of 1980-2000. Three alternative proxies have been used such as book-to-market equity, research and development expenditures and long term growth forecast for the investment opportunities in the OLS coefficients. It also recommended an increase in the investment opportunities as a result of abnormal changes in capital expenditures on abnormal changes in stock liquidity. Therefore, it shows a positive significant relation in comparison to the capital expenditures and variations in the stock liquidity.

Iqbal (2012) reassesses the important aspect of stock market focussing on the post-liberalization period in Pakistan. A complete overview of the Pakistan stock market has been analysed in respect of performance and measurement. The sample shows the salient features of the Pakistan stock market compared with a set of developing and emerging markets. Although being smaller in size, Pakistan stock market has considerably being more active as compared to the size of other such markets. Amihud (2002) examines that the relationship between price changes and trade volume affects the assets return. NYSE stock has been sampled for the data collection from 1964-1997. The heteroscedasticity test is employed to the study that asset expected returns are rising in illiquidity. Every change in the market illiquidity leads to the excess return on the stocks of smaller firms in the country. It is concluded that risk premium increases due to stock illiquidity. In short-term, stock excess return also reflects the lower liquidity in stock compared to treasury securities rather than just higher risk. This excess returns represents higher cost of capital for firms and thus limit their investment opportunities. The relationship between liquidity and stock returns is examined by Marshall (2006) in the Australian stock market. Using the data of 1100 listed firms from 1994-1998 he finds that there is significant positive relation between stock illiquidity and excess returns accros all the measures of illiquidity and abnormal returns. The study reported the interesting fact that size became significant when the excess return on the market was dropped from the regression. The liquidity proxies have no consistency in time variation and seasonality in the relationship of liquidity and returns. Nevertheless, the relationship between return and size is negatively correlated in the Australian market.

Hovakimian (2011) examines that to which extent the external capital markets have implications for their internal capital allocation. The results indicate that during recessions external financing costs are higher, and conglomerates significantly increase the efficiency of internal capital markets, the development is more significant for conglomerates that are likely to face more compulsory financial constraints. These findings also recommend that although financial constraints damage managers' ability to undertake a positive net present value projects, however, by reducing internal and external liquidity, the quality of project selection can be improved that may enhance valuable investment opportunities.

Kadapakkam, Kumar \& Riddick (1998) examine the effects of cash flow on firm investment in six developed markets. Where they documented that the level of corporate investment is influenced by internal financing (internal liquidity) in all developed markets. Further, by dividing the sample into three measures of firm size, they find that the cash flow-investment 
sensitivity is, usually, more in the large size firms as compared to small size firms. Hegde \& McDermott (2003) examine the effect of liquidity revisions by using S\&P 500 index as sample from 1993-1998. They employ the event study methodology to outline the estimation of abnormal returns. They find significant relation between reductions of bid-ask price spread and abnormal returns.

Lipson \& Mortal (2009) also examine the link between the capital structure and the equity market liquidity. Firms that have extensive stock liquidity will tend to have low leverage, thus firms raise their capitals by issuing equity finances. Five different measures are used to calculate the stock liquidity in relation to the capital structure. Those who are involved in the equity trading plays a major role in the stock market liquidity. Thus, stock liquidity has a significant impact on capital structure. Batten \& Vo (2014) study the relationship of stock returns and liquidity in Vietnam stock market by using the data set which is collected during the financial crisis from 2006-2010. Instead of bid-ask system in Vietnam stock market, the turnover rate of the asset is used as proxy of liquidity and find significant relation. Lewellen \& Lewellen (2014) examine investment-cash flow sensitivities of American companies from 1971-2009, where they document that financing and free cash flow problems are very important for investment decisions. Whereas liquidity plays a vital role in asset pricing, it could also help in improving the stock returns to the investors even during the financial crisis.

To extend the work done by Amihud (2002) illiquidity, Kang \& Zhang (2014) liquidity measure combines the virtues of the original Amihud ratio and the non-trading-frequency measure. The findings indicate that there is a higher correlation with the spread and price impact than other existing low-frequency liquidity measures in most of the sample markets. Further, they find that the liquidity in emerging markets, as measure of AdjILLIQ might be improved through better disclosure and less asymmetry information. Moreover, they concluded that the liquidity dry-up during market downturns. Lischewski \& Voronkova (2012) examine whether liquidity is a priced risk factor in emerging markets? Their findings are consistent with the developed markets regarding market size and value factors. The results support that stock price response is the function of growth opportunities of the offering firms.

Alfaro et al. (2004) examine the relationship between the economic growth and the stock market development for the effects of the stock market volatility and the banking system. They find a positive significant relationship of growth with stock market. Thus, stock markets and banks would be able to promote the economic growth of the firms. Considerable increase in investment opportunities is positively significant to the cost of capital (external liquidity) and the growth opportunities. Overall, in reviewing the existing literature; the findings and results of different studies show that investment opportunities are positively associated with a firm stock liquidity (external liquidity) and cash flows (internal liquidity). Since in this study we use the effective spread of stocks as a proxy for external liquidity, which in fact is a measure of illiquidity therefore, we expect a significant negative association between our measure of external liquidity and investment opportunities. For internal liquidity we use the ratio of operating cash flows to total assets and therefore, we expect a positive relation with investment opportunities. Market-to-book ratio, firm size, leverage and dividend payout ratio are used as control variables as investment opportunities are also affected by these variables. 


\section{DATA SAMPLE AND EMPIRICAL MODEL}

This section describes the data collection process adopted for this study to select firms from the BSE and KSE. The data are collected from DataStream and variables are calculated as described in the measurement of variable section below.

This study examines only the non-financial companies and removed the financial services companies from the data set. Thus, the sample is a reduced sub-sample of the firms listed on BSE and KSE. All the necessary data are extracted for the period of 2010-2015 from the DataStream. The script codes are acquired from the BSE and KSE, but the DataStream has a different data stream code for all the companies. So, list of company's data stream codes are obtained by using the Industry Classification Benchmark (ICB) along with the classification of the sector. We employed the annual data in analysis and the data are pooled into the cross-sectional time series panel data. There are a few limitations in the data collection, such as some of the variables information for a particular year is missing in the DataStream database. Such firms for the data are missing in a particular year are removed from the final sample. This study has a final dataset of non-financial firms for 208 firms listed on BSE and 136 firms listed on KSE. Whereas, the initial sample consisted of 250 firms in each of the BSE and KSE, but 156 companies are dropped due to missing data and delisted firms from the stock exchange during the study time period.

\section{DATA DESCRIPTION AND EMPIRICAL MODEL}

To examine the hypotheses this study used cross-sectional time series panel data to estimate the model (Becker-Blease \& Paul, 2006). This study includes the variable for the measurement of the investment opportunities in the South Asian emerging markets of India and Pakistan. By following major literature on investment opportunity and firm internal and external liquidity (Becker-Blease \& Paul, 2006), we employed pooled OLS fixed effect model of the following form:

$$
\begin{aligned}
\text { CAPEX }_{i t}= & \beta_{0}+\beta_{1} \text { MTBV }_{i t}+\beta_{2} \text { Levg }_{i t}+\beta_{3}{\text { Ext. } \text { Liqit }_{i t}}+\beta_{4} \text { Size }_{i t}+\beta_{5} \text { Int. Liqit }_{i t} \\
& +\beta_{6} D P O_{i t}+\varepsilon_{i t} \ldots \text { Equ } 1
\end{aligned}
$$

Where; CAPEX=Investment opportunities, which is measured as the ratio of capital expenditure divided by total assets

$M T B V=$ Market to book ratio, which is measured as market capitalization divided by book value of equity

Levg. $=$ Leverage ratio of the firm, which is measured as total debt divided by total assets Ext.Liqit= External liquidity of the firm, which is measured as midpoint price of ask and bid prices

Size $=$ Size of the firm, which is measured as market capitalization divided by total assets Int.Liqit=Internal liquidity, which is measured as cash flows from operations divided by total assets

$D P O=$ Dividend payout ratio, which is measured as DPS/EPS or total dividend paid divided by total net income, and $\varepsilon$ is the model error term. 
To control the endogeneity between firm internal and external liquidity and investment opportunity in the above model (Eq. 1), the study employed the GMM estimator system which is developed by Blundell \& Bond (1998). In this methodology, we employed lagged instruments of the endogenous variables to control endogeneity of the explanatory variables used in the pooled panel data. The reliability of the GMM estimator system pivots significantly on whether the lagged of explanatory variables are a valid set of instruments, and are not serially correlated. The difference Sargan analysis is used to ascertain the validity of the instrument variables. A first order serial correlation check performs to check whether the error term suffers from serial correlation.

\section{MEASUREMENT OF VARIABLES}

\section{Dependent Variable}

Investment Opportunities: Capital expenditure-to-total assets ratio is used to proxy the investment opportunity of a firm. Several other measures have been employed in the previous studies for the investment opportunities. Research and development expenditure is used as a proxy of the investment opportunities to estimate the profitability of the new investment (Denis, 1994). Capital expenditure ratio is used as proxy for the growth opportunities by Myers \& Majluf (1984), Becker-Blease \& Paul (2006) and Hoshi, Kashyap \& Scharfstein (1991). Capital expenditure means the amount incurred in the business for creating future benefits to the firms. In the current study we use capital expenditure is the ratio of capital expenditure incurred divided by total assets. Normally, capital expenditure incurs when a firm spends a certain amount of money to invest in the assets or to add value to the existing assets.

\section{Independent Variables}

External Liquidity: Effective spread, as calculated below, is used as a proxy for capturing the external illiquidity of the firm. To calculate effective spread, generally, closing ask and bid prices are used unless real-time prices are accessible. Ask and bid prices are stored each day at the closing time of the market and these prices are then adjusted for the subsequent capital actions, if any. The adjusted prices turn into the default price and it is then accessible for the investors and researchers. There are different types of proxies been used for the measurement of external liquidity i.e. effective spread, relative spread, quoted spread and the turnover ratio (Hegde \& McDermontt, 2003; Amihud, 2002; Marshall, 2006; and Iqbal, 2012). Following the most common historical literature we use the effective spread proxy to measure the external liquidity, which is described as following. The effective ask-bid spread is the absolute value of the difference between the price at which an investor is ready to sell and buy a security/ investment. The percentage value is used in this study. The equation is written as follows:

$$
\begin{aligned}
\text { Effective Bid }- \text { Ask Spread } & =2 * \frac{[\text { Transaction Price }- \text { Midpoint Price }]}{\text { Midpoint Price }} \ldots \text {... Equ } 2 \\
\text { Midpoint Price } & =\frac{(\text { Ask Price }+ \text { Bid Price })}{2} \ldots \text { Equ } 3
\end{aligned}
$$

In fact the above formula indicates that the effective spread will be higher for illiquid stocks whereas lower for liquid stocks. Thus it is expected that it will have significant negative relation with investment opportunities. 
Internal Liquidity: Operating cash flow to total assets ratio is used as proxy for internal liquidity. Some researchers use free cash flow, which is the difference between operating cash flow and investment cash flow, to measure the internal liquidity or internal financing available to a firm. Generally, cash flow is a generic term which is defined accordingly by the firms and even researcher for their own purpose. This study uses the proxy for internal liquidity value by taking cash flow from operating activities divided by total assets (Becker-Blease \& Paul, 2006). So this study uses both internal and external liquidity proxies. Internal liquidity is expected to have significant positive relation with investment opportunities.

\section{Control Variables}

Historical research shows that there a number of variables which effect the capital expenditure of a firm including its growth opportunities, size, capital structure and dividend policy. To control for such factors the current study includes these variables as statistical control variables so that the effect of liquidity can be studied in their presence.

Market-to-Book Value: Market to book value ratio is defined as the market value of the common equity (market capitalization) divided by the book value common equity (residual book value) of the firm. It is a measure of a firm's worth in the present time as compared to the amount invested in the firm by the past or the present shareholders. The market value of the firm is measured by the market capitalisation and book value is the residual book value of that firm. There are other measures used for capturing this ratio i.e. Lipson \& Mortal (2009) measured the market to book value by calculating the market value of a firm assets divided by the book value of assets. Since it is difficult to objectively measure the market value of firm total assets therefore, we use the most commonly used proxy used in the literature. Since higher market to book ratio is an indication of growth firms therefore, it is expected to be positively associated with investment opportunities.

Leverage: Total debt-to-total assets ratio is used as a proxy for the leverage ratio as it indicates the percentage of the firm's assets financed through debt. High leveraged means that the firm's assets are largely financed through debt and therefore, more expose to financial risk. Historically, some researchers have used debt to equity ratio as a proxy for the leverage (Hoshi et al., 1991) but in this study we use total debt-to-total assets ratio as a proxy for leverage. Higher leverage ratio is expected to positively associate with investment opportunities.

Firm Size: Market capitalisation divided by total assets is used as a proxy for firm size. There are many other proxies used to capture the size of a firm including natural log of total assets, net sales, and market capitalization. At country level, market size is estimated by using the ratio of market capitalization of the stock exchange over gross domestic product by Iqbal (2012), Levine \& Zervos (1998), Beck \& Levine (2004). Thus, different researchers follow different types of measurements for the Size. In the current study we use firm level size and therefore, use the ratio of market capitalization-to-total assets. Since large size firms have more opportunities to invest therefore, it is expected to have a significant positive relation with investment opportunities.

Dividend Payout: Dividend per share divided by earning per share is used as a proxy for dividend payout ratio. It is described a part of the earnings which is paid to the investors, and therefore no more available to the firm for investing in growth opportunities. Investment

76 Jan-June $2017 \quad$ Volume $1 \quad$ Number $15 \quad$ JISR-MSSE 
opportunities are inversely affected by the dividend payout (Denis, 1994). Some researchers have used dividend yield instead of dividend payout ratio to measure this variable. But in this study we use the dividend payout ratio. Dividend payout ratio is expected to be significantly negatively associated with investment opportunities. Some managers also pursue a managed distribution policy (MDP)-a dividend commitment potentially requiring the liquidation of assets (Cherkes, Sagi, \& Wang, 2015). In such situation payout may not directly be linked with investment opportunities.

\section{EMPIRICAL RESULTS AND ANALYSIS}

\section{Descriptive Statistics}

Table 1: Descriptive Statistics

\begin{tabular}{lccc}
\hline India & Mean & Median & Std.Dev. \\
\hline CAPEX & 0.4936 & 0.3289 & 0.7728 \\
\hline Int.Liqit. & 0.9723 & 0.5948 & 1.3216 \\
\hline Size & 16.7890 & 13.5287 & 0.9836 \\
\hline MTBV & 1.7826 & 1.3982 & 1.6439 \\
\hline Levg. & 0.6947 & 0.370 & 0.8746 \\
\hline Ext.Liqit. & 2.3829 & 1.6835 & 0.8931 \\
\hline DPO & 0.4279 & 0.3470 & 0.2465 \\
\hline Pakistan & & & 0.9823 \\
\hline CAPEX & 0.5026 & 0.2980 & 0.8024 \\
\hline Int.Liqit. & 0.9764 & 0.6028 & 0.9036 \\
\hline Size & 13.6834 & 11.6720 & 0.9877 \\
\hline MTBV & 1.4829 & 1.0946 & 0.9203 \\
\hline Levg. & 0.6063 & 0.4097 & 0.8750 \\
\hline Ext.Liqit. & 1.7823 & 1.4927 & 0.7819 \\
\hline DPO & 0.2063 & 0.1084 & \\
\hline
\end{tabular}

Note: CAPEX=Investment Opportunities, Int.Liqit=Internal liquidity, Size=Capitalization/Asset, MTBV=Market-to-book value, Levg.= debt-to-total assets ratio, Ext.Liqit.=External Liquidity, and DPO=dividend payout ratio

This study examines the sample of 344 non financial listed firms ( 208 from BSE and 108 from KSE) by using following dependent variable (capital expenditure) proxy for the investment opportunities, Internal and External Liquidity as independent variables and the MTBV, Levg., Size, and DPO ratio as control variables. The summary of descriptive statistics for both India and Pakistan shows mean, median, and standard deviation for each of the variable included in the study. The values for both sets of data are fairly consistent. It is evident from the results that the Indian firms are larger in size as compared to Pakistan and their payout ratio is higher than Pakistan. The effective spread in Pakistan is lower than India which shows that KSE is more liquid than BSE. The other variables are fairly similar. 


\section{Regression Results}

This study examines the relationship between investment opportunities and liquidity (internal and external) in the presence of MTBV, leverage, and DPO by using pooled OLS fixed effect method.

Table 2: OLS Coefficients for the BSE

\begin{tabular}{lccc}
\hline & OLS & Fixed Effect & IV-Model \\
\hline Constant & 0.6782 & 0.7262 & 0.9287 \\
\hline MTBV & $(0.464)$ & $(0.908)$ & $(0.768)$ \\
\hline & $0.2689 * *$ & $0.1833^{* *}$ & $0.2969 * * *$ \\
\hline Levg. & $(0.126)$ & $(0.0709)$ & $(0.089)$ \\
\hline Ext.Liqit. & $0.1706^{* * *}$ & $0.1908 * * *$ & $0.2469 * * *$ \\
\hline & $(0.056)$ & $(0.043)$ & $(0.009)$ \\
\hline Size & $-0.3298 * *$ & $-0.3298^{* * *}$ & $-0.2540 * *$ \\
\hline Int.Liqit. & $(0.046)$ & $(0.079)$ & $(0.0905)$ \\
\hline & $0.3762^{* * *}$ & $0.2946 * * *$ & $0.2672 * *$ \\
\hline DPO & $(0.104)$ & $(0.098)$ & $(0.104)$ \\
\hline & $0.1209 * *$ & $0.1426 * *$ & $0.1079 * *$ \\
\hline CAPEXit-1 & $(0.061)$ & $(0.072)$ & $(0.045)$ \\
\hline & $-0.1865 * * *$ & $-0.1680 * * *$ & $(0.046)$ \\
\hline AR(1) & $(0.033)$ & $(0.021)$ & $0.0618 * * *$ \\
\hline Diff. Sargan & $(0.7047)$ & & $(0.006)$ \\
\hline NORM $(2)$ & $(0.4098)$ & $(0.8464)$ & $(0.5684)$ \\
\hline Adjusted $\mathrm{R}^{2}$ & $52.74 \%$ & $(0.5067)$ & $(0.3496)$ \\
\hline
\end{tabular}

Note: $C A P E X=I n v e s t m e n t$ Opportunities is the dependent variable, MTBV=Market to book value, Levg.= debt-total assets ratio, Ext.Liqit.=External Liquidity, Size=Capitalization/Asset, Int.Liqit=Internal liquidity, and DPO means dividend payout ratio. The Sargan test follows degrees of freedom under the null hypothesis of valid instruments. NORM (2) is the significance of the Jarque-Bera tests normality. $A R(1)$ is the first order Lagrange multiplier test for the first difference of residual serial correlation. SE is in (.)

$* * *$ indicate significance at $1 \%, * *$ indicate significance at $5 \% \& *$ indicate significance at $10 \%$ significant level

Table 2 represents the OLS estimators of the model for BSE where capital expenditure as dependent variable, internal and external liquidity as independent variables and market to book value, leverage, and dividend payout ratio are the control variables of the model. The OLS regression coefficients of external liquidity represent significant negative relationship with investment opportunities. As mentioned earlier that the effective spread is, in fact, a measure of stock illiquidity and therefore significant negative relation is expected with investment opportunities. Based on the significant negative coefficient we accept the alternate hypothesis. The coefficient of internal liquidity is statistically positive significant for fixed effect and IV-Model at a 10\% level of significance but is insignificant in OLS model. This also partially justifies our alternate hypothesis that internal liquidity is positively associated with investment opportunities. The coefficients of control variables are also statistically significant as hypothesized in the study. For example, MTBV, leverage and size are positively associated 
with investment opportunities whereas DPO is negatively associated with investment opportunities in BSE. The value of adjusted R2 is above $50 \%$ in all three models for BSE which is very good. Sargan value, AR and NORM test values are all in the acceptable range therefore the results are robust.

Table 3: OLS Coefficients for the KSE

\begin{tabular}{lccc}
\hline & OLS & Fixed Effect & IV-Model \\
\hline Constant & 0.1242 & 0.1869 & 0.2068 \\
\hline MTBV & $(0.283)$ & $(0.918)$ & $(0.164)$ \\
\hline Levg. & $0.1608^{* * *}$ & $0.1395^{* *}$ & $0.1848^{* * *}$ \\
\hline & $(0.012)$ & $(0.062)$ & $(0.017)$ \\
\hline Ext.Liqit. & 0.8366 & 0.7965 & $0.6974 * *$ \\
\hline & $(0.684)$ & $(0.902)$ & $(0.204)$ \\
\hline Size & $-0.6515^{* * *}$ & $-0.5963^{* *}$ & $-0.6083^{* * *}$ \\
\hline & $(0.209)$ & $(0.214)$ & $(0.190)$ \\
\hline Int.Liqit. & $0.6290 * * *$ & $0.6133^{* * *}$ & $0.5894 * *$ \\
\hline & $(0.006)$ & $(0.148)$ & $(0.189)$ \\
\hline DPO & 0.2536 & $0.3075^{* *}$ & $0.1957 * *$ \\
\hline & $(0.314)$ & $(0.125)$ & $(0.062)$ \\
\hline CAPEXit-1 & -0.2536 & $-0.3075^{* *}$ & $-0.1956 * *$ \\
\hline & $(0.314)$ & $(0.149)$ & $(0.072)$ \\
\hline AR(1) & & & $0.3629 * * *$ \\
\hline Diff. Sargan & $(0.618)$ & $(0.074)$ \\
\hline NORM(2) & $(0.306)$ & $(0.749)$ & $(0.396)$ \\
\hline Adjusted R & $39.47 \%$ & $(0.301)$ & $(0.786)$ \\
\hline
\end{tabular}

Note: $C A P E X=I n v e s t m e n t$ Opportunities is the dependent variable, MTBV=Market to book value, Levg.= debt-total assets ratio, Ext.Liqit.=External Liquidity, Size=Capitalization/Asset, Int.Liqit=Internal liquidity, and DPO means dividend payout ratio. The Sargan test follows degrees of freedom under the null hypothesis of valid instruments. NORM (2) is the significance of the Jarque-Bera tests normality. AR (1) is the first order Lagrange multiplier test for the first difference of residual serial correlation. SE is in (.)

$* * *$ indicate significance at $1 \%, * *$ indicate significance at $5 \%$ \& *indicate significance at $10 \%$ significant level

Table 3 represents the OLS estimators of the model for KSE where capital expenditure as dependent variable, internal and external liquidity as independent variables and market to book value, leverage, and dividend payout ratio are the control variables of the model. The OLS regression coefficients of external liquidity represent significant negative relationship with investment opportunities. As mentioned earlier that the effective spread is, in fact, a measure of stock illiquidity and therefore significant negative relation is expected with investment opportunities. Based on the significant negative coefficient we accept the alternate hypothesis. The coefficient of internal liquidity is statistically positive significant for fixed effect and IV-Model at 5\% and 1\% level of significance, respectively, but, similar to BSE, is insignificant in OLS model. This also partially justifies our alternate hypothesis that internal liquidity is positively associated with firm's investment opportunities. The coefficients of control variables are also statistically significant as hypothesized in the study. For example, 
MTBV, leverage and size are positively associated with investment opportunities whereas DPO is negatively associated with investment opportunities in KSE. The coefficients of leverage are insignificant both in OLS and fixed effect model whereas the coefficient of DPO is insignificant in OLS model for KSE firms. The value of adjusted R2 varies from around 40\% to $60 \%$ the three models for KSE which is still a good value. Sargan value, AR and NORM test values are all in the acceptable range therefore the results are robust.

\section{DISCUSSION AND CONCLUSION}

This study analyse the relationship between firm's investment opportunities and internal and external liquidity and other control variables in the South Asian emerging markets of India and Pakistan. To test the hypotheses of this study, data are collected for the firms listed on BSE and KSE. Appropriate statistical tests are applied to test the association between investment opportunities and firm's liquidity in the presence of control variables. The results show that firm's stock illiquidity (external illiquidity) negatively affects its investment opportunities by limiting its ability to generate capital for NPV positive projects. This is consistent with the findings of historical literature available on the topic as well as with standard finance theory that stock illiquidity increases the WACC of a firm. The finding is consistent in both BSE and KSE listed firms.

Similarly, firm's internal liquidity is significantly positively associated with firm's investment opportunities. Those firms which have access to internally generated finances are better able to undertake more investment opportunities. Here again the results are consistent with historical research and standard finance theory. As the pecking order theory states that firms try to avoid generating external financing therefore, may compromise on some investment opportunities. On the other hand, firms with higher internal liquidity are not exposed to such constraints and therefore, their investment opportunities increase. The results for the control variables are also consistent with historical research and standard finance theory. Firms with large size are able to capitalize on more investment opportunities. Similarly, firms with higher debt ratio represent that such firms can generate the required funds for investment from debt market. Therefore, firm with high leverage have investment opportunities. MTBV is a sign of growth firms and therefore it positively associated with firm's investment opportunities. Lastly, dividend payout decreases the funds available for investment and therefore it is negatively associated with investment opportunities.

As this study reveals that investment opportunity has a positive significant relationship with liquidity in the emerging markets, therefore, policy makers at government level should take steps to improve the stock market liquidity where firms will be able to generate capital for their investment. Similarly, firm level management should improve internal liquidity to increase their investment opportunities. Managers should also balance the dividend payout ratio so that shareholders receive regular dividends but not constraining the firm's investment opportunities. 


\section{REFERENCES}

Alfaro, L., Chanda, A., Kalemli-Ozcan, S., \& Sayek, S. (2004). FDI and economic growth: the role of local financial markets. Journal of international economics, 64 (1), 89-112.

Amihud, Y. (2002). Illiquidity and Stock Returns: Cross Section and Time Series Effects. Journal of financial markets, 5 (1), 31-56.

Amihud, Y., \& Mendelson, H. (1988). Liquidity and asset prices: Financial management implications. Financial Management, 17 (1), 5-15.

Batten, J. A., \& Vo, X. V. (2014). Liquidity and return relationships in an emerging market. Emerging Markets Finance and Trade, 50 (1), 5-21.

Beck, T., \& Levine, R. (2004). Stock markets, banks, and growth: Panel evidence. Journal of Banking \& Finance, 28 (3), 423-442.

Becker-Blease, J. R., \& Paul, D. L. (2006). Stock liquidity and investment opportunities: Evidence from index additions. Financial Management, 35 (3), 35-51.

Bekaert, G., Harvey, C. R., \& Lundblad, C. (2007). Liquidity and expected returns: Lessons from emerging markets. Review of Financial Studies, 20 (6), 1783-1831.

Bekaert, G., Harvey, C. R., \& Lundblad, C. T. (2003). Equity market liberalization in emerging markets. Journal of Financial Research, 26 (3), 275-299.

Blundell, R., \& Bond, S. (1998). Initial conditions and moment restrictions in dynamic panel data models. Journal of Econometrics, 87 (1), 115-143.

Bond, S., Leblebicioğlu, A., \& Schiantarelli, F. (2010). Capital accumulation and growth: a new look at the empirical evidence. Journal of Applied Econometrics, 25 (7), 1073-1099.

Budina, N., Garretsen, H., \& De Jong, E. (2000). Liquidity constraints and investment in transition economies. Economics of Transition, 8 (2), 453-475.

Campello, M., Giambona, E., Graham, R., \& Harvey, R. (2011). Liquidity management and corporate investment during a financial crisis. Review of Financial Studies, 24 (6), 1944-1979.

Carpenter, R. E., \& Petersen, B. C. (2002). Is the growth of small firms constrained by internal finance?. Review of Economics and Statistics, 84 (2), 298-309.

Carpenter, R. E., Fazzari, S. M., Petersen, B. C., Kashyap, A. K., \& Friedman, B. M. (1994). Inventory investment, internal-finance fluctuations, and the business cycle. Brookings Papers on Economic Activity, 1994 (2), 75-138 
Chen, H. J., \& Chen, S. J. (2012). Investment-cash flow sensitivity cannot be a good measure of financial constraints: Evidence from the time series. Journal of Financial Economics, 103 (2), 393-410.

Cherkes, M., Sagi, S., \& Wang, J. (2015). Managed distribution policies in closed-end funds and shareholder activism. Journal of Financial and Quantitative Analysis, 49 (5), 1311-1337.

Denis, D. J. (1994). Investment opportunities and the market reaction to equity offerings. Journal of Financial and Quantitative Analysis, 29 (02), 159-177.

Ding, S., \& Knight, J. (2011). Why has China grown so fast? The role of physical and human capital formation. Oxford Bulletin of Economics and Statistics, 73 (2), 141-174.

Ding, S., Guariglia, A., \& Knight, J. (2013). Investment and financing constraints in China: does working capital management make a difference? Journal of Banking \& Finance, 37 (5), 1490-1507.

Fazzari, S. M., \& Petersen, B. C. (1993). Working capital and fixed investment: new evidence on financing constraints. The RAND Journal of Economics, 24 (3), 328-342.

Gregoriou, A., \& Ioannidis, C. (2006). Information costs and liquidity effects from changes in the FTSE 100 list. The European Journal of Finance, 12 (4), 347-360.

Hegde, S. P., \& McDermott, J. B. (2003). The liquidity effects of revisions to the S\&P 500 index: An empirical analysis. Journal of Financial Markets, 6 (3), 413-459.

Hoshi, T., Kashyap, A., \& Scharfstein, D. (1991). Corporate structure, liquidity, and investment: Evidence from Japanese industrial groups. The Quarterly Journal of Economics, 100 (2), 33-60.

Hovakimian, G. (2011). Financial constraints and investment efficiency: Internal capital allocation across the business cycle. Journal of Financial Intermediation, $20(2), 264-283$.

Iqbal, J. (2012). Stock Market in Pakistan An Overview. Journal of Emerging Market Finance, 11 (1), 61-91.

Kadapakkam, R., Kumar, P. C., \& Riddick, A. (1998). The impact of cash flows and firm size on investment: The international evidence. Journal of banking \& Finance, $22(3), 293-320$.

Kang, W., \& Zhang, H. (2014). Measuring liquidity in emerging markets. Pacific-Basin Finance Journal, 27 (2014), 49-71. 
Kaplan, S. N., \& Zingales, L. (1997). Do investment-cash flow sensitivities provide useful measures of financing constraints?. The Quarterly Journal of Economics, 169-215.

Levine, R., \& Zervos, S. (1996). Stock market development and long-run growth. The World Bank Economic Review, 10 (2), 323-339.

Levine, R., \& Zervos, S. (1998). Stock markets, banks, and economic growth. American economic review, 88 (3), 537-558.

Lewellen, J., \& Lewellen, K. (2016). Investment and cash flow: New evidence. Journal of Financial and Quantitative Analysis, 51(4), 1135-1164.

Lipson, M. L., \& Mortal, S. (2009). Liquidity and capital structure. Journal of Financial Markets, 12 (4), 611-644.

Lischewski, J., \& Voronkova, S. (2012). Size, value and liquidity. Do they really matter on an emerging stock market?. Emerging Markets Review, 13 (1), 8-25.

Marshall, B. R. (2006). Liquidity and stock returns: Evidence from a pure order-driven market using a new liquidity proxy. International Review of Financial Analysis, 15 (1), 21-38.

Moyen, N. (2004). Investment-cash flow sensitivities: Constrained versus unconstrained firms. The Journal of finance, 59 (5), 2061-2092.

Myers, S. C. (1977). Determinants of corporate borrowing. Journal of financial economics, $5(2), 147-175$.

Myers, S. C., \& Majluf, S. (1984). Corporate financing and investment decisions when firms have information that investors do not have. Journal of financial economics, $13(2), 187-221$

Subrahmanyam, A., \& Titman, S. (2001). Feedback from stock prices to cash flows. The Journal of Finance, 56 (6), 2389-2413 


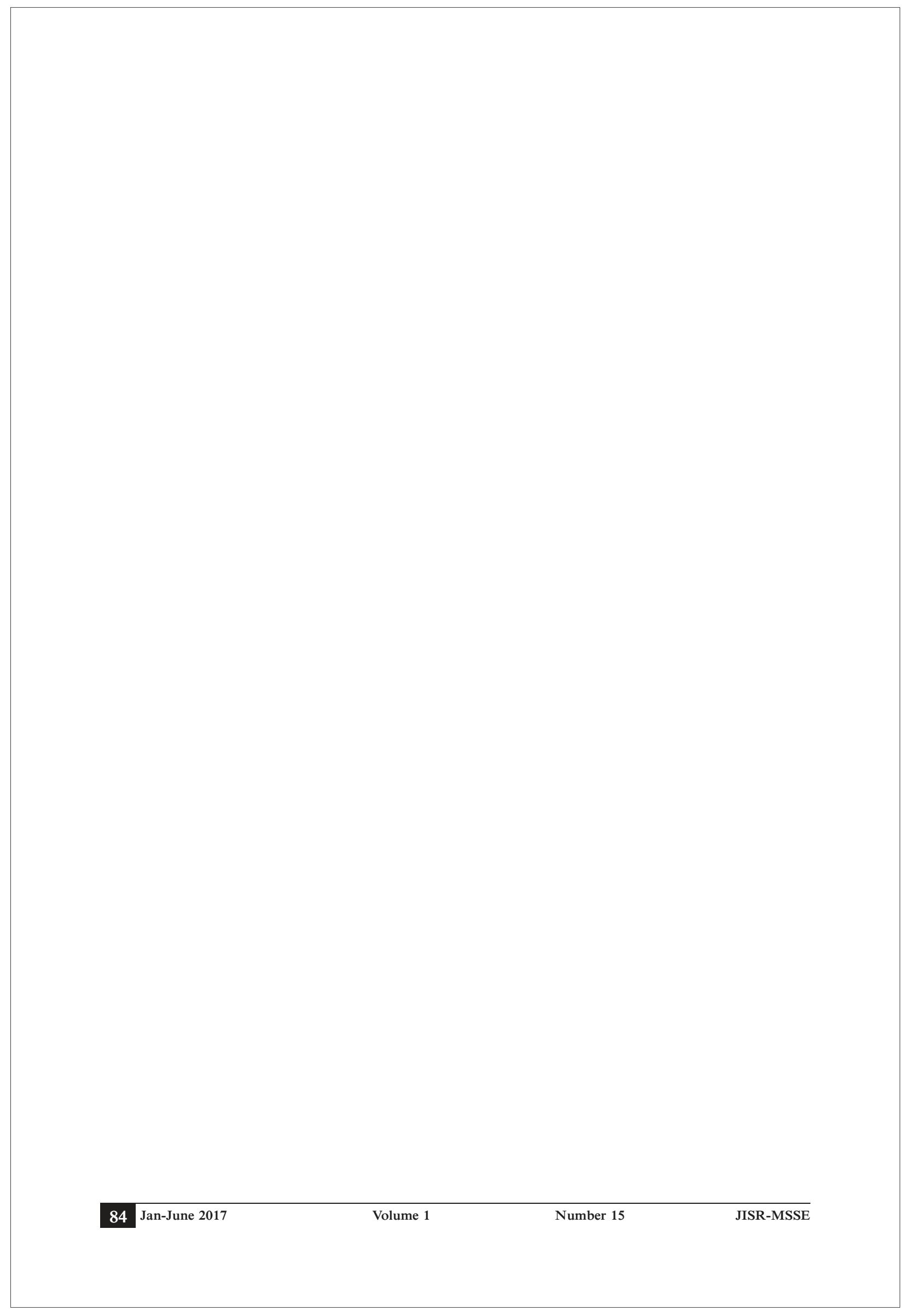

